\title{
DESKRIPSI KETERAMPILAN PROSES SAINS MAHASISWA PENDIDIKAN BIOLOGI MELALUI PEMBELAJARAN BERBASIS PRAKTIKUM PADA MATA KULIAH TAKSONOMI TUMBUHAN
}

Titin

FKIP Pendidikan Biologi Universitas Tanjungpura, Pontianak Email:titinbasuki@rocketmail.com

\begin{abstract}
Abstrak
Penelitian ini bertujuan untuk mengetahui deskripsi keterampilan proses sains mahasiswa pendidikan biologi melalui pembelajaran berbasis praktikum pada mata kuliah taksonomi tumbuhan. Metode penelitian yang digunakan adalah penelitian deskriptif. Sumber data dalam penelitian ini adalah mahasiswa reguler A program studi pendidikan biologi semester IV tahun akademik 2012/2013 FKIP Universitas Tanjungpura Pontianak yang terdiri dari 33 orang. Data mengenai keterampilan proses mahasiswa diperoleh dari tes tertulis. Untuk mengetahui deskripsi keterampilan proses mahasiswa dalam pembelajaran berbasis praktikum digunakan analisis deskriptif dengan teknik persentase. Hasil penelitian menunjukkan bahwa rata-rata persentase keterampilan proses pada setiap indikator berada dalam kategori sedang yaitu sebesar $46.75 \%$. Indikator keterampilan proses sains yang berada pada kategori tinggi yakni memprediksi sebesar $69.69 \%$, sedangkan yang berada pada kategori sangat rendah yakni hipotesis sebesar $12.12 \%$. Secara berurutan persentase indikator keterampilan proses dari hasil penelitian, yaitu memprediksi $(69.69 \%)$, mengamati (66.66\%), merencanakan percobaan (57.57\%), keterampilan menyimpulkan (54.54\%), mengajukan pertanyaan (39.39\%), interpretasi data $(27.27 \%)$ dan hipotesis $(12.12 \%)$.
\end{abstract}

Kata kunci : Keterampilan proses sains, , pembelajaran berbasis praktikum

FKIP Unasiswa pendidikan biologi

dibekali dua kompetensi selama berada dibangku perkuliahan yakni kompetensi keilmuwan materi biologi dan kompetensi pedagogik. Untuk mengembangkan kompetensi keilmuwan biologi, selain pemberian teori juga dibarengi dengan kegiatan praktikum. Penerapan pembelajaran sains biologi tidak hanya menekankan kepada konten yang berupa konsepkonsep, prinsip-prinsip, dan hukum- hukum di dalam sains tapi juga proses sains yang jauh lebih penting. Proses sains diberikan melalui pembelajaran berbasis praktikum, untuk itu praktikum memegang peran penting di dalam pembelajaran sains biologi. Hal ini terlihat dengan jumlah waktu yang dibutuhkan untuk praktikum lebih banyak dibandingkan pemberian teori. Dalam satu sks teori waktu yang diperlukan 50 menit sedangkan satu sks praktikum diperlukan 150 menit. 
Menurut definisi, sains adalah pengetahuan yang telah disusun secara sistematik, terorganisir, didapatkan melalui observasi dan eksperimentasi, serta bermanfaat bagi manusia. Mengacu kepada pengertian ini, jelas bahwa sains harus diawali dengan melakukan observasi dan eksperimentasi. Kemajuan ilmu dan teknologi saat ini sangat pesat sehingga tidak mungkin terkejar dengan cara mengajarkan konsepnya saja tetapi lebih penting menekankan kepada cara mendapatkan konsep

Praktikum menekankan pada proses pencarian pengetahuan dari pada transfer pengetahuan. Mahasiswa dipandang sebagai subjek belajar yang perlu dilibatkan secara aktif dalam proses pembelajaran, dosen sebagai fasilitator yang membimbing dan mengkoordinasikan kegiatan belajar mahasiswa.

Dalam pembelajaran berbasis praktikum, mahasiswa diajak untuk melakukan proses pencarian pengetahuan berkenaan dengan materi pelajaran melalui berbagai aktivitas proses sains sebagaimana dilakukan oleh para ilmuwan dalam melakukan penyelidikan ilmiah (Nur. 1998). Dengan demikian mahasiswa diarahkan untuk menemukan sendiri berbagai fakta, membangun konsep, dan nilai-nilai baru yang diperlukan untuk kehidupannya. Fokus proses pembelajaran diarahkan pada pengembangan keterampilan mahasiswa dalam memproses pengetahuan, menemukan dan mengembangkan sendiri fakta, konsep, dan nilai-nilai yang diperlukan (Semiawan, dkk. 1984). Mahasiswa diberikan kesempatan untuk langsung terlibat dalam aktivitas dan pengalaman ilmiah seperti apa yang dilakukan/dialami oleh ilmuwan. Dengan demikian mahasiswa dididik dan dilatih untuk terampil dalam memperoleh dan mengolah informasi melalui aktivitas berpikir dengan mengikuti prosedur (metode) ilmiah, seperti terampil melakukan pengamatan, pengukuran, pengkla-sifikasian, penarikan kesimpulan, dan penyampaian hasil temuan.

Praktikum merupakan strategi "guided discovery" yang membantu mahasiswa belajar untuk belajar ("learn to learn"), membantu mahasiswa memperoleh pengetahuan dengan cara menemukannya sendiri. Di dalam praktikum juga tercakup penemuan makna ("meanings"), organisasi, dan struktur dari ide atau gagasan, sehingga secara bertahap mahasiswa belajar bagaimana mengorganisasikan dan melakukan penelitian. Pembelajaran berbasis praktikum menekankan pada kemampuan siswa dalam menemukan sendiri ("discover") pengetahuan yang didasarkan atas pengalaman belajar, hukum-hukum, prinsipprinsip dan generalisasi. Dengan demikian mahasiswa lebih diberdayakan sebagai subjek belajar yang harus berperan aktif dalam memburu informasi dari berbagai sumber belajar, dan dosen lebih berperan sebagai organisator dan fasilitator pembelajaran.

Masalah dalam penelitian ini adalah "Bagaimana deskripsi keterampilan proses sains mahasiswa Pendidikan Biologi melalui pembelajaran berbasis praktikum pada mata kuliah taksonomi tumbuhan?".

Secara umum tujuan dalam penelitian ini untuk mengetahui 
deskripsi keterampilan proses sains mahasiswa pendidikan biologi melalui pembelajaran berbasis praktikum pada mata kuliah taksonomi tumbuhan.

\section{Metode}

Penelitian ini dilaksanakan di Program studi Pendidikan Biologi FKIP Universitas Tanjungpura Pontianak. Subyek penelitian ini adalah mahasiswa reguler $\mathrm{A}$ pendidikan biologi semester IV tahun akademik 2012/2013 yang terdiri dari mahasiswa laki-laki sebanyak 10 orang dan mahasiswa perempuan sebanyak 23 orang.

Metode penelitian yang digunakan adalah penelitian deskriptif. Dari hasil penelitian akan dideskripsikan keterampilan proses sains mahasiswa pendidikan biologi meliputi keterampilan proses sains dasar dan keterampilan proses sains terpadu.
Teknik pengumpulan data dalam penelitian ini menggunakan teknik pengukuran. Tes yang digunakan yaitu tes tertulis dengan bentuk essay. Soal tes essay yang diberikan kepada siswa digunakan untuk mengukur dan mengetahui keterampilan proses sains mahasiswa. Analisis data pada penelitian ini menggunakan analisis kuantitatif berupa persentase yang diperoleh dari skor yang diperoleh mahasiswa dibandingkan dengan skor total keseluruhan.

\section{Hasil}

Berdasarkan hasil tes tertulis yang diberikan kepada mahasiswa pendidikan Biologi reguler A semester IV tahun akademik 20012/2013, diperoleh hasil persentase $(\%)$ keterampilan proses sains seperti yang disajikan pada tabel di berikut ini:

Tabel 1: Persentase Kemampuan Keterampilan Proses Mahasiswa Pada Setiap Aspek Keterampilan Proses

\begin{tabular}{|c|c|c|c|c|}
\hline $\begin{array}{l}\text { No } \\
\text { Soal }\end{array}$ & Indikator & $\begin{array}{c}\text { Persentase } \\
(\%)\end{array}$ & $\begin{array}{c}\text { Rata } \\
\text { persentase }\end{array}$ & Kategori \\
\hline 1 & \multirow{2}{*}{ Mengamati } & 96.96 & \multirow[t]{2}{*}{66.66} & \multirow{2}{*}{ Baik } \\
\hline 10 & & 36.36 & & \\
\hline 2 & \multirow{2}{*}{ Mengajukan pertanyaan } & 45.45 & \multirow[t]{2}{*}{39.39} & \multirow{2}{*}{ Kurang } \\
\hline 4 & & 33.33 & & \\
\hline 3 & \multirow{2}{*}{ Interpretasi data } & 12.12 & \multirow[t]{2}{*}{27.27} & \multirow{2}{*}{ Kurang } \\
\hline 11 & & 42.42 & & \\
\hline 5 & Prediksi & 69.69 & 69.69 & Baik \\
\hline 6 & \multirow{3}{*}{ Merencanakan percobaan } & 63.63 & \multirow{3}{*}{57.57} & \multirow{3}{*}{ Sedang } \\
\hline 7 & & 63.63 & & \\
\hline 8 & & 45.45 & & \\
\hline 9 & Hipotesis & 12.12 & 12.12 & Kurang sekali \\
\hline 12 & Menyimpulkan & 54.54 & 54.54 & Sedang \\
\hline \multicolumn{3}{|c|}{ Total } & 46,75 & Sedang \\
\hline
\end{tabular}


Rata-rata indikator keterampilan proses sains yang diperoleh setelah pembelajaran berbasis praktikum pada mata kuliah taksonomi tumbuhan pada masingmasing jenis keterampilan proses baik dasar maupun terintegrasi termasuk dalam kategori sedang yaitu 46.75 . Empat keterampilan proses dasar yang termasuk dalam penelitian ini adalah keterampilan mengamati, mengajukan pertanyaan, prediksi dan menyimpulkan. Terdapat dua kategori baik (mengamati dan prediksi), satu kategori sedang (menyimpulkan) dan satu kategori kurang (mengajukan pertanyaan).

Tiga keterampilan proses terintegrasi yang termasuk dalam penelitian ini adalah keterampilan interpretasi data, merencanakan percobaan dan hipotesis. Terdapat satu kategori sedang (merencanakan percobaan), satu kategori kurang (interpretasi data) dan satu kategori kurang sekali (hipotesis).

Pada tabel 1 diketahui dari tujuh keterampilan proses yang diberikan dua keterampilan proses termasuk dalam kategori baik yakni mengamati $(66.66 \% \%)$, dan memprediksi (69.69\%), 2 keterampilan proses termasuk dalam kategori sedang yakni keterampilan merencanakan percobaan $(57.57 \%)$ dan keterampilan menyimpulkan (54.54\%), dua keterampilan proses termasuk kategori kurang yakni mengajukan pertanyaan $(39.39 \%)$ dan interpretasi data $(27.27 \%)$ dan satu keterampilan proses termasuk dalam kategori kurang sekali yakni membuat hipotesis (12.12\%).

\section{Pembahasan}

Keterampilan proses mengamati berada pada kategori baik. Keterampilan proses mengamati terdiri dari dua soal yakni nomor soal 1 dan nomor soal 10. Pada nomor soal 1 mahasiswa yang menjawab dengan benar sebesar $96.96 \%$, sebaliknya pada nomor soal 10 hanya $36.36 \%$ mahasiswa mampu menjawab dengan benar. Dari hasil wawancara dengan mahasiswa, pada nomor soal 10 banyak yang tidak dapat menjawab dengan benar dikarenakan mereka kurang teliti dalam membaca soal yang diberikan.

Keterampilan memprediksi mahasiswa berada pada kategori baik dimana mereka mampu untuk menggunakan pola-pola hasil pengamatan untuk menjawab pertanyaan. Keterampilan memprediksi berkaitan dengan kemampuan menalar mahasiswa. Hal ini sesuai dengan tahap-tahap perkembangan kognitif dalam teori Piaget, dimana mahasiswa termasuk ke dalam tahap operasional formal yakni sudah mampu berfikir abstrak dan logis dengan menggunakan metode berfikir ilmiah. Budiningsih (2008) menyatakan tahap operasional formal (umur 11/12-18 tahun). Ciri pokok perkembangan tahap ini adalah anak sudah mampu berfikir abstrak dan logis dengan menggunakan pola berfikir "kemungkinan" model berfikir ilmiah dengan tipe hypothetico-deductive dan inductive".

Keterampilan merencanakan percobaan berada pada kategori sedang. Meskipun termasuk keterampilan terintegrasi tetapi mahasiswa sudah terbiasa merencanakan percobaan dalam kegiatan praktikum pada mata kuliah 
taksonomi tumbuhan. Kegiatan merencanakan percobaan yang dilakukan mahasiswa antara lain menentukan alat dan bahan serta menyusun prosedur/langkah kerja, dan mengontrol variabel yang harus dilakukan saat praktikum. Hal ini sesuai dengan pernyataan Nuryani (2005), praktikum juga berfungsi untuk meningkatkan motivasi belajar, mengembangkan keterampilan dasar bereksperimen, wahana belajar pendekatan ilmiah, dan menunjang pemahaman materi pelajaran.

Keterampilan menyimpulkan berada pada kategori sedang. Mahasiswa sudah terbiasa melakukan kegiatan menyimpulkan terutama setelah kegiatan praktikum selesai dilakukan dan tertuang dalam laporan kegiatan praktikum yang dilakukan. Mahasiswa menyimpulkan berdasarkan petunjuk atau bukti yang meraka dapatkan dari hasil kegiatan.

Keterampilan mengajukan pertanyaan termasuk dalam keterampilan proses dasar, akan tetapi berada pada kategori kurang. Hal tersebut dikarenakan selama ini mahasiswa kurang diajak untuk melakukan eksplorasi dalam kegiatan praktikum dimana bentuk praktikumnya masih berupa "resep masakan". Mahasiswa hanya melakukan praktikum sesuai dengan prosedur yang dibuat oleh dosen dalam penuntun praktikum.

Keterampilan interpretasi data berada pada kategori kurang. Dari dua soal yang diberikan yakni nomor soal 3 dan 11, keduanya berada pada kategori kurang dimana persentasenya adalah $12.12 \%$ dan $42.42 \%$. Mahasiswa kurang memiliki kemampuan untuk menganalisis dan mengorganisasikan data dengan menentukan pola atau hubungan antar data.

Keterampilan membuat hipotesis berada pada kategori kurang sekali. Mahasiswa kurang mampu dan belum terbiasa untuk membuat suatu perkiraan yang beralasan untuk menerangkan suatu kejadian atau pengamatan tertentu.

\section{Simpulan dan Saran}

Kesimpulan dari penelitian ini adalah sebagai berikut:

1. Persentase indikator pada setiap keterampilan proses sains mahasiswa biologi Reguler A semester IV tahun akademik 2012/2013 berbeda-beda setelah pembelajaran berbasis praktikum pada mata kuliah taksonomi tumbuhan. Rata-rata persentase keterampilan proses untuk semua pada setiap indikator berada dalam kategori sedang yaitu sebesar 46.75 .

2. Indikator keterampilan proses sains yang berada pada kategori tinggi yakni memprediksi sebesar $69.69 \%$, sedangkan yang berada pada kategori sangat rendah yakni hipotesis sebesar $12.12 \%$. Secara berurutan persentase indikator keterampilan proses dari hasil penelitian, yaitu memprediksi (69.69\%), mengamati (66.66\%), merencanakan percobaan (57.57\%), keterampilan menyimpulkan $\quad(54.54 \%)$, mengajukan pertanyaan $(39.39 \%)$, interpretasi data $(27.27 \%)$ dan hipotesis $(12.12 \%)$.

3. Empat keterampilan proses dasar yang termasuk dalam penelitian ini adalah keterampilan mengamati, mengajukan pertanyaan, prediksi dan menyimpulkan. Terdapat dua 
kategori baik (mengamati dan prediksi), satu kategori sedang (menyimpulkan) dan satu kategori kurang (mengajukan pertanyaan).

4. Tiga keterampilan proses terintegrasi yang termasuk dalam penelitian ini adalah keterampilan interpretasi data, merencanakan percobaan dan hipotesis. Terdapat satu kategori sedang (merencanakan percobaan), satu kategori kurang (interpretasi data) dan satu kategori kurang sekali (hipotesis).

Untuk meningkatkan keterampilan proses sains mahasiswa dalam mengajukan pertanyaan dan mengajukan hipotesis, dosen hendaknya melibatkan kemampuan memecahkan masalah dalam kegiatan praktikum.

\section{Daftar Pustaka}

Budiningsih, AC. 2005. Belajar dan Pembelajaran. Jakarta: Rineka Cipta
Nur, M. 2011. Modul Keterampilan Proses Sains ( disadur dari INQURY SKILL ACTIVITY BOOK yang diterbitkan oleh Prentice-Hall,Inc.Upper

Saddle River,New Jersey 07458 pada tahun 2000). Pusat Sains dan Matematika Sekolah Universitas Negeri Surabaya.

Nuryani.YR. 2002. Keterampilan Proses Sains. Makalah SPS UPI Bandung

Semiawan, C. Pangyong, AF, Bellen, S. Matahelemual, Y dan Suseloardjo, W. 1984. Pendekatan Keterampilan Proses "Bagaimana Mengaktifkan Siswa Dalam Belajar”. Jakarta: PT Gramedia Widiasarana Indonesia. 
Deskripsi Keterampilan Proses Sains 53 